\title{
A rebelde do sertão Maria da Cruz e o motim de 1736*
}

\author{
The rebel of sertão \\ Maria da Cruz in the riot of 1736
}

\author{
AleXANDre RODRIGUeS DE SOUZA** \\ Departamento de História \\ Universidade Federal Fluminense \\ Niterói (RJ) \\ Brasil
}

RESUMO Figura lendária no sertão das Minas Gerais e imortalizada nas páginas de Diogo de Vasconcelos, Maria da Cruz teve seu nome ligado aos conflitos políticos que sacudiram o sertão das Minas no ano de 1736. Este artigo procura analisar a presença de Maria da Cruz na revolta.

Palavras-chave Maria da Cruz, sertão, motim de 1736

ABSTRACT Legendary figure in the sertão of Minas Gerais and immortalized in the pages of Diogo de Vasconcelos, Maria da Cruz had his name linked to the political conflicts that shook the sertão of Minas in the year 1736. This article seeks to analyze the presence of Maria da Cruz in revolt.

Keywords Maria da Cruz, sertão, riot of 1736

\footnotetext{
* Artigo recebido em: 10/02/2012. Aprovado em: 15/06/2012.

** Este artigo incluiu parte das discussões da minha pesquisa para a dissertação de mestrado orientada pelo Prof Dr. Luciano Figueiredo na Universidade Federal Fluminense. A dissertação contou com auxílio financeiro do Instituto Cultural Amilcar Martins, através da bolsa Pesquisador da História de Minas/2010. Agradeço também a Capes por garantir, no final do trabalho de pesquisa, as condições para o término da mesma. Sou grato ao Luciano por ter acompanhado a escrita deste artigo com interesse e sugestões. Contato: axrsouza@gmail.com.
} 


\section{Apresentação}

Tudo conspirava contra ela. Vivia em um ambiente adverso e malvisto pelas autoridades coloniais: o sertão. Seu cunhado estava envolvido na revolta. Seu filho dava postos aos enfurecidos. Tinha em sua casa um ferreiro rebelde que lhe era confidente, além das más amizades que, supostamente, cultivava por ali. E para colocar mais lenha nessa fogueira, era mulher. Naquela época, apenas isso parecia capaz de condená-la.

Figura lendária no sertão, Maria da Cruz foi imortalizada na escrita de Diogo de Vasconcelos devido a sua participação no motim de 1736 em Minas. Nas páginas que dedica à personagem, o autor combinou uma boa dose de imaginação às fontes que consultou. O escritor mineiro fez uma biografia heróica sobre essa figura feminina das Minas Gerais no início do século XIX. Diogo de Vasconcelos disse que conseguiu "raros e dispersos vestígios" sobre Maria da Cruz, mas mesmo diante desses indícios "incompletos e muito deficientes", foi capaz de rabiscar algumas palavras para que o leitor tivesse a imagem dessa "matrona" em mente. A mulher que "tanto contribuiu para urbanizar o sertão do S. Francisco", aparece em sua obra como uma figura:

Alta, compleição robusta, cabelos branqueados, olhos negros, e, pelo que dela sabemos de positivo, é que foi inteligentíssima e altiva, deixando, portanto, traduzir na feição própria do sexo, as linhas enérgicas do ânimo senhoril. Por isso foi adorada pelos parentes. E, todavia, ei-la, o modelo dos poderosos, aí humilhada presa, ré de lesa-majestadade. ${ }^{1}$

Maria da Cruz aparece com uma forma feminina poderosa, vigorosa e experiente. Ela é construída na obra de Diogo de Vasconcelos como a mulher que veio para purgar o sertão bárbaro. O autor desenha uma pessoa de pulso forte. É uma verdadeira "virago" do sertão, assim conceituou Laura de Mello e Souza. ${ }^{2}$

O conflito em que Maria da Cruz esteve envolvida ficou conhecido como Motins do Sertão. ${ }^{3}$ Nome consagrado pela historiografia e que dá título ao conjunto de protestos que sacudiram o sertão das Minas entre os meses de março e agosto de 1736. O próprio Martinho de Mendonça de Pina e

1 VASCONCELOS, Diogo de. História média de Minas Gerais. Belo Horizonte: Imprensa Oficial, 1918, p.137.

2 SOUZA, Laura de Mello e. Norma e conflito: aspectos da história de Minas no século XVIII. Belo Horizonte: Editora da UFMG, 1999, p.90.

3 Essa nomeação aparece em: MOTINS do sertão e outras occorrencias em Minas Gerais durante o governo interino de Martinho de Mendonça de Pina e de Proença, conforme a correspondência deste com o governo da metrópole; extractos de livro do Arquivo. Revista do Arquivo Público Mineiro (doravante RAPM), Ouro Preto, v.1, n.4, 1896; cf. ANASTASIA, Carla Maria Junho. Vassalos rebeldes: violência coletiva nas Minas na primeira metade do século XVIII. Belo Horizonte: C/Arte, 1998, p.61-83. Luciano Figueiredo, embasado num conjunto de fontes inéditas sobre o tema, rebatizou para "furores sertanejos" esses conflitos; cf. FIGUEIREDO, Luciano Raposo de Almeida. Furores sertanejos na América Portuguesa: rebelião e cultura política no sertão do Rio São Francisco, Minas Gerais, 1736. Oceanos, Lisboa, p. 128-144, 1999. 
de Proença, governador interino da capitania de Minas na época, numa de suas cartas chegou a contabilizar esses motins. Segundo ele, "é certo que no fim de março houve tal qual tumulto contra o Juiz do Papagaio", outro no meio de maio, contra o comissário André Moreira, o terceiro em São Romão, "no dia seis de julho", e ainda um novo movimento em meados do mês de agosto. Todas essas "assuadas" acontecidas no ano de 1736. ${ }^{4}$ Tratava-se de uma região com fortes ligações com a Bahia, ponto de formação e de conexão com o sertão das Minas. ${ }^{5}$ Era uma terra de fronteira, de criadores de gado e de comércio entre as Minas e a Bahia.

Martinho de Mendonça chamava esse território da capitania de "confins deste governo". Expressão corrente nas cartas do governador na época, quando se referia à região do sertão. Essa elocução também foi fruto das muitas dores de cabeça que o administrador interino das Minas enfrentou para entender o que se passava naquelas paragens, no decorrer do ano de $1736 .{ }^{6}$

Governar uma terra onde "o clima é tumba da paz e berço da rebelião"7 não era tarefa fácil. Difícil, mais ainda, foi convencer D. Maria da Cruz e os moradores daquele sertão a pagarem a Capitação. ${ }^{8}$ Essa nova cobrança de direito régio instituída em 1735 determinava que todos os moradores das Minas, inclusive os criadores de gado, passariam a pagar um valor anual fixo, sobre o número de escravos que possuíam. A nova contribuição deixou os moradores do sertão do São Francisco muito aborrecidos. Foi uma empreitada penosa para Martinho de Mendonça. O governador confessou em carta que a "conspiração ou levante do sertão foi a matéria mais importante" de seu governo. ${ }^{9}$

A tarefa de descobrir a identidade dos rebeldes também foi custosa. Martinho de Mendonça reitera ainda que nos motins de Minas era comum os "cabeças" não aparecerem publicamente. ${ }^{10}$ Além disso, Maria da Cruz

4 CARTA de Martinho de Mendonça de Pina e de Proença a Gomes Freire de Andrada. Vila Rica, 13 ago. 1736. Arquivo Nacional da Torre do Tombo (doravante ANTT), Manuscritos do Brasil (doravante Mss. do Brasil). Livro 3, fl.149-149v. Os documentos com lotação ANTT, citados nesse trabalho, resultam da transcrição do Prof. Dr Luciano Figueiredo. Agradeço ao prof. Luciano Figueiredo pela concessão dessas fontes, que fizeram parte da sua pesquisa de doutorado, financiada pela Coordenação de Aperfeiçoamento de Pessoal de Nível Superior (CAPES - Brasil): FIGUEIREDO, Luciano. Revoltas, fiscalidade e identidade colonial na América Portuguesa (Rio de Janeiro, Bahia e Minas Gerais, 1640- 1761). São Paulo: Universidade de São Paulo, 1996 (História, Tese de doutorado). Ressalto aqui que o acesso as essas fontes se deve ao comprometimento desse historiador com os trabalhos de seus orientandos e alunos.

5 CARRARA, Ângelo Alves. Antes das Minas Gerais: conquista e ocupação dos sertões mineiros. Varia História, Belo Horizonte, v.23, n.38, p.574-596, jul./dez. 2007.

6 Martinho de Mendonça governou a capitania de Minas entre 15 de maio de 1736 e dezembro de 1737. Sobre a figura e a prática de governança de Martinho de Mendonça. Cf. CAVALCANTI, Irenilda Reinalda Barreto de Rangel Moreira. O comissário real Martinho de Mendonça: práticas administrativas portuguesas na primeira metade do século XVIII. Niterói, RJ: Universidade Federal Fluminense, 2010 (História, Tese de doutorado).

7 DISCURSO Histórico e Político sobre a Sublevação que nas Minas houve no ano de 1720. Estudo Crítico de Laura de Mello e Souza. Belo Horizonte: Fundação João Pinheiro, Centro de Estudos Históricos de Culturais, 1994, p.59.

8 FONTES históricas do imposto da Capitação. RAPM, Belo Horizonte, v.12, p.605-676, 1907.

9 CARTA de Martinho de Mendonça para Antônio Guedes Pereira - Secretário de Estado. Vila Rica, 23 dez. 1737. RAPM, Ouro Preto, v.1, n.4, p.666, 1896.

10 CARTA de Martinho de Mendonça ao juiz de Papagaio. Arquivo Público Mineiro (doravante APM). Seção Colonial (doravante SC) 54, fl.20-20v. Disponível em: <http://www.siaapm.cultura.mg.gov.br> Acesso em: 10 dez. 2010. 
e os outros revoltosos viviam nas lonjuras do sertão. ${ }^{11}$ A composição social amotinada também era bastante diversa, portanto mais difícil de hierarquizar as "cabeças" rebeldes.

No dia 8 de julho de 1736, o Intendente do Serro Frio Francisco da Cunha Lobo, escrevia ao governador dizendo que a "sedição daqueles insolentes" amotinados insistia no ódio à capitação. Francisco da Cunha estava ciente da ameaça e instabilidade que uma revolta poderia causar, por isso colocava-se disposto a estudar mais de perto aquela "hidra". ${ }^{2}$

A metáfora da hidra foi bastante utilizada pelos governantes na Época Moderna como arquétipo das muitas cabeças amotinadas. Símbolo da "desordem e da resistência", ela era uma verdadeira ameaça aos governos. ${ }^{13} \mathrm{O}$ mito justificava também as proporções desiguais na hora de impor a ordem sobre a massa de sublevados. Era preciso hierarquizar aquelas cabeças amotinadas. A figura mitológica era mais que uma forma de linguagem, representava o medo e explicava a violência dos representantes régios frente aos sublevados. Logo, o recurso ao símbolo pressupunha que a revolta tinha várias cabeças. A multidão revoltosa tinha múltiplas faces e era preciso, portanto, classificá-las.

Na América portuguesa essa insígnia também esteve presente nas análises dos governadores frente aos súditos descontentes. Fonte principal para o estudo da revolta de Vila Rica em 1720, o Discurso Histórico e Político sobre a sublevação que nas Minas houve no ano de 1720, por exemplo, fez referência ao modo como os governadores utilizavam suas definições de categorias sociais para entender a participação ou o grau de responsabilidade dos rebeldes nas revoltas, afirma Laura de Mello e Souza. ${ }^{14}$ Aos olhos dos governadores, a simbologia da hidra parecia explicar a ação dos insurgentes e também aproximá-los da sua noção de poder..$^{15}$

A hidra que representava os revoltosos do sertão era composta por três tipos de "cabeças", garantiu Martinho de Mendonça. Sendo que

11 ARAÚJO, Emanuel. Tão vasto, tão ermo, tão longe: o sertão e o sertanejo nos tempos coloniais. In: DEL PRIORE, Mary. (org.). Revisão do paraíso: os brasileiros e o estado do Brasil em 500 anos. São Paulo: Campus, 2000, p.45-91.

12 CARTA de Francisco da Cunha Lobo a Martinho de Mendonça. Tiririca, 8 jul. 1736. APM. SC 54, fl. $106 v-107$. Disponível em: < http://www.siaapm.cultura.mg.gov.br>. Acesso em: 10 dez. 2010.

13 O monstro que permeava o imaginário daqueles homens era uma representação feminina "filha de Tifão (tempestade ou furacão) e Equidna (metade mulher, metade cobra) era parte de uma ninhada de monstros que incluía Cérbero, o cão de três cabeças, Quimera, bode com cabeça de leão e cauda de cobra, Gerião, gigante de corpos, e Esfinge, a mulher com corpo de leão". Reza a lenda que no momento em que Hércules "decepou uma das cabeças da hidra nasceram duas novas no lugar." Mas foi com a ajuda de seu sobrinho lolau que ele conseguiu matar a fera "decepando-lhe a cabeça central e cauterizando o coto com um tição". Após várias flechadas conseguiu "o poder letal que lhe permitiu completar os trabalhos". LINEBAUGH, Peter; REDIKER, Marcus. A hidra de muitas cabeças: marinheiros, escravos, plebeus e a história oculta do Atlântico Revolucionário. São Paulo: Companhia das Letras, 2008, p.9-15.

14 SOUZA, Laura de Mello e. Estudo crítico. In: DISCURSO Histórico e Político sobre a sublevação que nas Minas houve no ano de 1720

15 SOUZA, Laura de Mello e. O sol e a sombra: política e administração na América portuguesa do século XVIII. São Paulo: Companhia das Letras, 2006, p.242-243. 
os primeiros, e principais, são homens poderosos no país, e estabelecidos neles, que acostumados a viver sem outra lei que a da sua vontade, procuraram impedir o pagamento da Capitação (...) Também se podem reputar segundos cabeças, e na aparência são as primeiras, quatro ou cinco pessoas que tinham pouco, ou nada a perder (...) e o terceiro lugar parecem cabeças o General, Secretário e Juiz do Povo, ainda que realmente não o são, porque nestes empregos introduziram gente meio rústica e tanto que entendo, conheciam a atrocidade do delito, como se colhe das perguntas, principalmente de Simeão Corrêa, um mestiço que nunca entrou em povoado a quem fizeram General das Armas. ${ }^{16}$

Nesse mecanismo de hierarquização social, os valores étnicos e socioeconômicos são levados em consideração. Martinho de Mendonça classifica as principais cabeças rebeldes como homens de cor branca. São os potentados locais que estão ali vivendo naquele sertão "sem outra lei que a da sua vontade" e procuravam "impedir o pagamento da capitação", afirmou o governador. O grupo era composto ainda de "cabeças" de segunda escala, identificados como "ocultamente instigados dos outros". Por último, a multidão era representada por "cabeças" de "gente meio rústica". ${ }^{17}$

\section{A rebelde}

Maria da Cruz foi arrolada como uma das "principais cabeças" do levante. Dessa hidra, ela era uma das primeiras. Juntava-se a rebelde o seu cunhado Domingos do Prado e o seu filho Pedro Cardoso. Esses também listados como aqueles que ocupavam as primeiras fileiras dos conflitos. Segundo o governador, tratava-se de indivíduos que "muito se atendem às parentelas e a amizades". ${ }^{18}$ Em carta, Martinho de Mendonça completava a sua classificação, apontando os principais personagens envolvidos nos tumultos sertanejos e também os seus delitos.

Assim descreveu o governador: o capitão Manuel Afonso de Sequeira e seu sobrinho André Gonçalves Siqueira eram "autores do primeiro tumulto de Montes Claros" contra o comissário André Moreira de Carvalho no mês de maio de 1736. O vigário Antônio Mendes Santiago era o "principal motor do motim de São Romão". Luis de Sequeira Brandão, homem poderoso, se retirou para os matos e se conservou retirado. Domingos de Prado foi

16 CARTA de Martinho de Mendonça ao secretário de estado Antônio Guedes. Vila Rica, 16 dez. 1736. RAPM, Ouro Preto, v.1, n.4, p.652, 1896. Irenilda Cavalcanti analisa as "cabeças amotinadas" dos motins sertanejos. CAVALCANTI, Irenilda R. B. R. M. Cabeças amotinadas: Martinho de Mendonça e o motim de 1736 nos sertões mineiros. In: TAVARES, Célia Cristina da Silva; RIBAS, Rogério de Oliveira. (orgs.). Hierarquias, raça e mobilidade social. Rio de Janeiro: Contra Capa, 2010, p.201-214.

17 CARTA de Martinho de Mendonça ao secretário de estado Antônio Guedes. Vila Rica, 16 dez. 1736. RAPM, Ouro Preto, v.1, n.4, p.652-53, 1896. As "terceiras cabeças" amotinadas receberam análise no trabalho de Gefferson Ramos Rodrigues. O autor politiza a participação de escravos e índios na revolta. Cf: RODRIGUES, Gefferson Ramos. No sertão, a revolta: grupos sociais e formas de contestação na América portuguesa, Minas Gerais, 1736. Niterói, RJ: Universidade Federal Fluminense, 2009 (História, Dissertação de mestrado).

18 INSTRUÇÃO de Martinho de Mendonça a Manuel Dias Torres (Intendente da fazenda Real da comarca de Sabará). Vila Rica, 1 mai. 1737. APM. SC 61, fl.60-61. Disponível em: <http://www.siaapm.cultura.mg.gov.br>. Acesso em: dez. 2010. 
acusado de mandar "um barril de pólvora" para os levantados. Pedro Cardoso, filho de D. Maria da Cruz, era quem dava os postos aos amotinados. Teodósio Duarte servia como general das armas na revolta. Quanto a Maria da Cruz, essa "foi a casa do ferreiro Francisco de Souza seu paisano para escrever carta a Prado quando havia de ter o primeiro levante". ${ }^{19}$

$\mathrm{Na}$ denuncia a rebelde aparece como uma espécie de mensageira da desordem. E era assim que as autoridades coloniais queriam que ela fosse vista. Aquela sociedade, ainda marcadamente misógina, acreditava no poder transgressor das mulheres. Ainda não conheciam muito bem, mas tinham certeza da existência do suposto obscuro poder feminino.20 Nesse momento, o mais perigoso era o de fazer com que os homens as acompanhassem na hora da desordem. Afinal, Eva havia feito o mesmo. ${ }^{21}$ O pecado e a desobediência estavam nas mãos da figura feminina, e as autoridades coloniais também agiam confiantes nisso.

Não se pode esperar, é claro, que as mulheres participem das revoltas da mesma maneira que os homens. Sua atuação é diferente. Em texto onde destaca a presença feminina nos motins da Europa Moderna, Arlette Farge adverte que o "papel das mulheres na revolta é, antes de tudo, o de não nos espantarmos com esta evidência, é saber que só a inversa seria surpreendente". ${ }^{22}$ Quando se tratava de mulheres presentes no corpo político amotinado, fica difícil entender como, "a partir de que mecanismos de falta e compensações o furor e o gosto da morte" pode existir naquelas que são responsáveis pela vida. ${ }^{23}$

Em estudo sobre os motins da Inglaterra do século XVII, Edward P. Thompson ressalta a presença de homens e mulheres que engrossavam

19 INSTRUÇÃO de Martinho de Mendonça a Manuel Dias Torres (Intendente da fazenda Real da comarca de Sabará). Vila Rica, 1 mai. 1737. APM. SC 61, fl.60-61. Disponível em: <http://www.siaapm.cultura.mg.gov.br> Acesso em: 10 dez. 2010. Paisano: "Natural da mesma terra". Indivíduos que são companheiros. BLUTEAU, Raphael. Vocabulario portuguez \& latino: aulico, anatomico, architectonico ... 8 v. Coimbra: Collegio das Artes da Companhia de Jesus, 1712-1728. p.187-188. Disponível em: <http://www.brasiliana.usp.br/en/dicionario>. Acesso em: 10 dez. 2010.

20 Segundo Natalie Davis, durante o "início da era moderna na Europa o sexo feminino era visto como o sexo desregrado por excelência". O discurso médico da época dizia que o sexo feminino era composto de "humores frios e úmidos". Essa "frialdade e umidade indicavam um temperamento instável, enganoso e falso". Logo, de acordo com o discurso da época, as mulheres "só podiam torna-se histéricas". As mulheres eram conhecidas por sua "imaginação indisciplinada" e tinham o hábito de "soltar sua língua em público". DAVIS, Natalie Zemon. As mulheres por cima. In: _. Culturas dos povos: sociedade e cultura no início da França Moderna. Rio de Janeiro: Paz e Terra, 1990, p.107.

21 Padre Antonio Vieira lembrava: "Se Eva se contivera dentro do Paraíso que Deus Ihe tinha dado por morada, e não quisera ver mais mundo, ela se livrara dos encontros em que viu e ouviu o que não Ihe convinha; mas, porque quis sair e andar por fora, por amor do mundo, que fora melhor não ver, não só perdeu o mesmo mundo, senão também o Paraíso, e a si a nós. E isto é que sucede cada dia ás filhas de Eva". VIEIRA, Antônio. Sermão XVII. In: Sermões. v.9, São Paulo: Américas, 1957, p.431. Os discursos médico, religioso, moral, jurídico e social da Época Moderna, por exemplo, concentraram seus esforços no sentido de que a figura feminina não se esquecesse do terrível pecado que havia cometido no jardim do Éden; cf. DUBY, Georges; PERROT, Michelle. (orgs.). História das mulheres no Ocidente: do Renascimento à Idade Moderna. v.3. Porto: Afrontamento, 1993.

22 FARGE, Arlette. Agitadoras notórias. In: PERROT, Michelle; DUBY, Georges. (orgs.). História das mulheres no ocidente: do Renascimento à Idade Moderna. Porto: Afrontamento, 1991, p.569.

23 FARGE, Arlette. O sabor do arquivo. São Paulo: Edusp, 2009, p.44. Nesse livro, a autora, através de um relato de experiência com documentos policiais da França do século XVIII, discute a relação entre o uso do arquivo e a escrita da história. Arlette Farge foi sensível à "presença dela", da mulher, nesses fundos. 
a aglomeração "imbuídos da crença de que estavam defendendo direitos costumeiros tradicionais". A presença de mulheres nos chamados "motins de fome" se explica pelo fato delas serem "as mais envolvidas com as negociações face a face no mercado, as mais sensíveis ao significado dos preços, as mais experientes em detectar peso insuficiente ou qualidade inferior". ${ }^{24}$ Durante as revoltas elas ocupavam "as primeiras filas" com seus "gritos" e também "engrossam a multidão com sua presença". ${ }^{25}$ Afinal, quando se trata do "mítico imposto sobre a vida, são as mulheres, em primeiro lugar e, sobretudo, que creem nele". ${ }^{26}$

Entretanto, a participação de Maria da Cruz nos motins do sertão foi distinta dessas agitadoras que iam para a rua. Ela e seus parentes eram uma elite sertaneja que "por si e seus antepassados descobriram estes sertões e os povoaram a custa de seu sangue e fazendas conquistando dele o gentio bravo". Estavam ali a "perca de muitas vidas há mais de quarenta anos, povoando as ditas terras com fazendas de gado". ${ }^{27}$ Maria da Cruz fazia parte de uma elite sertaneja atrás de seus direitos de conquista cuja memória familiar não deixava esquecer.

Assunto presente na boca das elites revoltosas: a conquista, o povoamento e a defesa da colônia foram argumentos recorrentemente utilizados pelos colonos como forma de lembrar ao monarca os seus direitos na condição de súditos. Trata-se também de um discurso utilizado em outros momentos, como na Guerra dos Emboabas em 1709, e também pelos "naturais da terra" na Guerra dos Mascates, em 1710. ${ }^{28}$ Essa tópica, muito comum nas revoltas da América portuguesa aparece, por exemplo, nas alterações dos súditos pernambucanos que, através da "restauração alcançada 'à custa de nosso sangue, vidas e fazendas', criaram a existência de um pacto entre a Coroa e a 'nobreza da terra', o qual teria estabelecido em favor de um tratamento preferencial". ${ }^{29}$ Luciano Figueiredo analisou a presença desse topos nas inúmeras situações de revoltas na América portuguesa. ${ }^{30}$

No sertão essas elites estavam escondidas atrás da turba revoltosa. Esses potentados tiveram papel importante na conformação política de

24 THOMPSON, Edward Palmer. Costumes em comum: estudos sobre a cultura popular tradicional. São Paulo: Companhia das Letras, 1998, p.152-184.

25 FARGE, Arlette. Agitadoras notórias, p.559-560.

26 DELUMEAU, Jean. História do medo no ocidente (1300-1800). São Paulo: Companhia das Letras, 1989, p.189.

27 Esse foi o discurso que o "troço de gente sertaneja" gritou ao se dirigirem ao juiz ordinário de São Romão, Francisco de Souza Ferreira. REQUERIMENTO dos moradores do sertão do São Francisco ao general Gomes Freire, redigido e registrado pelo tabelião do distrito de São Romão Alexandre de Castro Roiz, tendo como juiz ordinário Francisco Soares Ferreira. São Romão, 6 jul. 1736. ANTT. Mss. do Brasil, Liv 10, fl.38-39, fl.38-39.

28 MELLO, Evaldo Cabral de. A fronda dos Mazombos: Nobres contra Mascates, 1666-1715. 2 ed. São Paulo: Editora 34,2003, p.321.

29 MELLO, Evaldo Cabral de. Rubro veio: o imaginário da restauração pernambucana. Rio de Janeiro: Nova Fronteira 1986, p.100-128.

30 FIGUEIREDO, Luciano Raposo de Almeida. Narrativas das rebeliões: linguagem política e idéias radicais na América Portuguesa moderna. Revista USP, São Paulo, n.57, p.6-27, mar./mai. 2003. Nesse texto o autor também retira de modo definitivo da leitura nativista que dificultava a compreensão das revoltas na América portuguesa. 
Minas nessas áreas de conquista. ${ }^{31}$ Numa comunidade que era fundada também no exercício do mando, ${ }^{32}$ os poderosos classificados como "cabeças principais" tinham a função de "emocionar o povo até a sedição". ${ }^{33}$ Os potentados do sertão agiam se valendo do poder de representatividade que tinham dentro daquela sociedade. A elite sertaneja canalizou a autoridade popular com base na posição que ocupavam localmente.

Maria da Cruz fazia parte da elite descontente do sertão das Minas e utilizou desse posto para aglutinar revoltosos a sua causa. É justamente essa ação coletiva e o seu envolvimento íntimo com pessoas ligadas ao movimento que provocaram desconfianças das autoridades. Francisco de Souza, por exemplo, foi considerado o "principal motor das inquietações" em Brejo do Salgado. Segundo o governador, ele e Maria da Cruz eram "amigos confidentes". Porém, por resistir à prisão, o mataram. A morte de Francisco de Souza foi lamentada por Martinho de Mendonça, pois havia enorme interesse do governador "nas perguntas" aplicadas ao amotinado. Um certo mistério rondava a figura de Maria da Cruz, já que a morte do ferreiro de sua casa foi considerada "perda grande", pois nas perguntas se poderia evidenciar as "grandes luzes do que ainda se encobre da terrível conspiração do levante", garantiu Martinho de Mendonça. ${ }^{34}$

Martinho de Mendonça esteve desassossegado com a presença dessa mulher no corpo político rebelde. Em novembro de 1737, quando os amotinados já se achavam presos e diante de total insegurança, o governador pediu que o "Juiz Ordinário tirasse um sumário procurando averiguar correspondências sediciosas com o pretexto das conferências de Francisca Machado com Maria da Cruz". Na ótica do governador, essas mulheres estariam se juntando para espalhar a desordem. Conforme vimos, já havia uma denúncia de que Maria da Cruz escreveu uma carta a Domingos do Prado dando sinal para o primeiro levante. Nesse momento, a suposta habilidade de Maria da Cruz com as letras é usada novamente como forma de incriminar a personagem. Martinho de Mendonça, em tom de indignação, retruca que "os que podem ser cabeças não pretendem mais que dar-me um desgosto ou fazer-me um ultraje". ${ }^{35}$

Se dependesse da imaginação desses homens, a mulher era quase que naturalmente portadora da desordem. As negras de tabuleiro, que viviam nos

31 Cf. SANTOS, Marcio Roberto Alves dos. Bandeirantes paulistas no sertão do São Francisco: povoamento e expansão pecuária de 1688 a 1734. São Paulo: Edusp, 2009.

32 Os valores como honra, valentia, virilidade e fama pública estruturavam essa sociedade. Célia Nonata da Silva, embasada no conceito de cultura política mestiça, caracteriza a natureza e as formas de poder existente em regiões de fronteira da America portuguesa como sociedades onde se configuraram os territórios de mando; cf. SILVA, Célia. Nonata. Territórios de mando: bantiditismo em Minas Gerais, século XVIII. Belo Horizonte: Crisálida, 2007.

33 CHARTIER, Roger. A história cultural: entre práticas e representações. In: _. Cultura política e cultura popular no Antigo Regime. Lisboa: Difel, 1990, p.198.

34 CARTA de Martinho de Mendonça a Gomes Freyre. Vila Rica 28 out. 1737. ANTT. Mss. do Brasil, Livro 3. fl.334-334v.

35 CARTA de Martinho de Mendonça a Gomes Freyre. Vila Rica o primeiro de novembro de 1737. ANTT. Mss. Brasil, Livro 3, fl.337-339. 
arredores da mineração, também não eram bem vistas pelas autoridades coloniais. Elas eram acusadas de desviarem os escravos do trabalho com suas guloseimas e cachaças. Os donos de vendas e negras de tabuleiro foram frequentemente delatados por desviarem ouro e diamantes, provocando conflitos e desordens. Para as autoridades coloniais, as mulheres estariam mesmo mais propensas às desordens quando se ajuntavam. Segundo Luciano Figueiredo, durante os motins de 1720 em Vila Rica houve uma intensa repressão à circulação das vendas pelas ruas. A movimentação dessas mulheres poderia ajudar a espalhar, ainda mais, os planos de sedição. ${ }^{36} \mathrm{O}$ "Discurso Histórico..." alertava sobre as lamentações dos

moradores do bairro de Antônio Dias e do Padre Faria que aquelas vendas eram refúgio certo dos seus negros fugidos, os quais, tendo nelas quanto lhes era necessário, não desciam abaixo muito meses, e ocultando-se dos senhores, a quem não davam jornal, era pouco todo o ouro que adquiriam para fielmente deixar nas ditas vendas, que pela maior parte Ihes serviam também lupanares, comércio abominável, trato vil e ganho ilícito dos brancos, que nelas punham, ou para melhor dizer expunham, negras gentis para mais pronta saída, fácil consome dos seus efeitos, e segura atração dos negros, que até para as suas obscenidades ali achavam asseadas camas. ${ }^{37}$

Havia uma clara relação entre a moral e a transgressão política. Essas mulheres causavam um perigo social aliado a uma suposta imoralidade pública. O secretário do governo de Minas, Manuel de Azevedo, encaminhou ao rei, em 1732, uma representação onde deixava bem explícito o risco da imoralidade das mulheres que feriam a ideia de um governo politico baseado em princípios cristãos. O secretário avisava que várias vezes os senhores retiravam de suas "casas das vendas, dando os passeios" e ofereciam lugar para que as negras ficassem "desembaraçadas para o uso de seus apetites". ${ }^{38}$ Ao mesmo tempo em que temia-se o desvio de quintos, eram também consideradas imorais as desordens que elas propiciavam.

A relação entre mulheres, prostituição e sedição povoava a cabeça das autoridades. Francisca Machado, a amiga de Maria da Cruz que provocou tanta desconfiança do governador devido as suas "correspondências sediciosas" com a rebelde, apareceu nas cartas de Martinho de Mendonça como uma

mulher pública, que esteve presa, por constar que em sua casa Francisco Miguel de Orquide, e seus sócios [fizeram] os primeiros ensaios de moeda falsa, a quem

36 FIGUEIREDO, Luciano Raposo de Almeida. O avesso da memória: cotidiano e trabalho da mulher em Minas Gerais no século XVIII. Rio de Janeiro: Olympio, 1999, p.51.

37 DISCURSO Histórico e Político sobre a sublevação que nas Minas houve no ano de 1720, p.73.

38 REPRESENTAÇÃO do secretário de governo de Minas, Manuel de Azevedo ao Rei, em 1732. In: BARBOSA, Waldemar de Almeida. Negros e quilombos em Minas Gerais. Belo Horizonte: s.ed., 1972, p.120-123. O documento se encontra também em: APM. SC 35 
a lubricidade do Ouvidor, e Juiz do Fisco, contra toda forma de direito facilitou a soltura, entendendo por meio de um termo de denuncia antidatado, e reduzirão com sugestões, e máquinas, o Secretário a um extremo, que parecia loucura, ainda que entende que não poderão alcançar que ele descobrisse os segredos das disposições para o sertão, que com grande empenho se desejava penetrar. ${ }^{39}$

A amizade de Maria da Cruz com uma "mulher pública" também ajudava a incriminá-la. Essa era uma sociedade que primava pela distinção e pelas lícitas relações de amizade. Das relações e correspondências de Maria da Cruz com o ferreiro Francisco de Souza e com Francisca Machado, Martinho de Mendonça não descobriu mais do que "suspeitas incertas". ${ }^{40} \mathrm{O}$ governador estava atrás da mulher perigosa, armadora, fraca de espírito e desordeira. Características que qualificava esse tipo de mulheres na época.

Além disso, num período em que as relações sociais mais do que determinavam o caráter das pessoas, estar envolvido com indivíduos de má fama já era mais que suficiente para a condenação. A fama qualificava as relações sociais daquela sociedade, mas também era elemento desqualificador dependendo das afinidades dos indivíduos. ${ }^{41}$

Outra particularidade que marca a presença de Maria da Cruz na revolta é a companhia de seu filho. Arlette Farge discorre sobre o maciço comparecimento da mulher e dos filhos nos protestos da Época Moderna. Segundo a autora, o "filho é um lugar, é também um lugar de honra", tanto da "família como da vizinhança". Acompanhar "a mãe na revolta é a marca do lugar que ocupa entre a família e a cidade, marca efetiva, mas também simbólica". Arlette Farge lembra que a "figura da feminilidade aliada à da juventude adiciona gravidade e legitimidade aos levantamentos populares", pois introduzem "a imagem simultânea de uma dupla vontade subversiva, encarnada num desejo de restauração da justiça e de inovação". ${ }^{42}$

O "erro da traição" também estava baseado nos preceitos de linhagem. Ele condenava quem o fazia e determinava a infâmia dos "que de sua linha descendem", mesmo que "não tenham culpa". Nessa sociedade, o crime de "Lesa Majestade" era comparado à lepra, "porque assim como a enfermidade enche todo o corpo, sem nunca mais se poder curar, e empece ainda aos descendentes de quem a tem, e aos que com ele conversão". ${ }^{3}$

39 CARTA de Martinho de Mendonça para o Secretário de Estado Antônio Guedes Pereira. Vila Rica, 23 dez. 1737. RAPM, Ouro Preto, v.1, n.4, p.668, 1896. Segundo BLUTEAU, Raphael. Vocabulário portuguez e latino, "Mulher Pública" é "meretriz", "Magana (..) moças de má vida".

40 CARTA de Martinho de Mendonça a Gomes Freyre. Vila Rica o primeiro de novembro de 1737. ANTT. Mss. Brasil, Livro 3, fl.337-339.

41 Análise sobre a força representativa da fama pública na sociedade mineira da época foi feita em: SILVEIRA, Marco Antônio. Fama pública: poder e costume nas Minas setecentistas. São Paulo: Universidade de São Paulo, 2000 (História, Tese de doutorado).

42 FARGE, Arlette. Agitadoras notórias, p.562

43 "DO CRIME DE LESA MAJESTADE". Ordenações Filipinas. Fontes Históricas do Direito Português. Livro V, Tit. 6. IUS LUSITANIAE. Disponível em: < http://iuslusitaniae.fcsh.unl.pt/verlivro.php?id_parte=88\&id_obra=65\&pagina=12>. Acesso em: 10 mar. 2011. 
Havia um claro princípio de linhagem que levava esse tipo de mazela a todos os indivíduos que cercavam o criminoso, tanto por parte da descendência, como pela sua sociabilidade.

Nesse sentido, o fato de Pedro Cardoso ser filho de Maria da Cruz já era motivo para desconfianças. Seu irmão, Mathias Cardoso, também despertou suspeitas de estar envolvido no tumulto. Este, no início da revolta, "não chegou a declarar-se", somente depois de passados o motim "se mostrou bom servidor de El Rey". Havia dúvidas quanto à fidelidade de Mathias Cardoso, pois o "seu capelão o Padre Antônio Fernandes de Matos se correspondia com os levantados". ${ }^{44}$ Mas logo este filho de Maria da Cruz se revelou mais apto ao serviço de seu Rei.

Nessa arena política entre submissão e rebeldia, de um lado uns aceitam a capitação, demonstrando fidelidade régia, enquanto outros vassalos instigam a rebelião. ${ }^{45}$ Tanto que depois da revolta foi feito, para a região do sertão, um documento onde apareciam listadas as pessoas que tinham postos militares naquelas paragens. O objetivo era identificar aqueles que a coroa poderia contar naquele território inflamado. Mathias Cardoso aparece com o posto militar na região de Urucuia, sendo "esta ribeira a mais populosa e afluente que tem o sertão do rio de S. Francisco". No texto ele foi descrito como a "pessoa que mais zelosa se mostrou" aos serviços, tanto que "no seu próprio pagamento como na cobrança da Capitação dos mais moradores" o súdito realizou "com zelo, inteligência e prontidão". ${ }^{46}$ Desde outubro de 1736, ele estava mais disposto ao partido de seu Rei. Em carta chegou a oferecer a sua casa ao capitão dos dragões, José de Morais Cabral, para que descansasse antes de seguir sua viagem para Goiás. O filho de Maria da Cruz ficou pronto a ajudar o seu senhor em qualquer tipo de serviço. ${ }^{47}$ Matias Cardoso foi ainda encarregado de fazer a cobrança da capitação no sertão. ${ }^{48}$

O exemplo mostra como uma rede parental não implica necessariamente boas relações, ainda mais quando se trata do ambiente das contestações. Nesse momento conflituoso e instável, obediência e rebeldia estavam em jogo. Evaldo Cabral de Mello, em estudo sobre a Guerra dos Mascates, discutiu como "a sedição da nobreza foi uma revolução de parentes, o que, aliás, é característica de toda fronda nobiliárquica". Segundo o autor,

44 INSTRUÇÃO de Martinho de Mendonça a Manuel Dias Torres Vila Rica, 1 mai. 1737. APM. SC 61, fl.60-61. Disponível em: <http://www.siaapm.cultura.mg.gov.br>. Acesso em: 10 dez. 2010.

45 FIGUEIREDO, Luciano. Adesão, risco e lealdades: repressão aos rebeldes (séculos XVII e XVIII). Comunicação apresentada no III Colóquio Internacional Raízes do privilégio: Hierarquia e Mobilidade Social no Mundo Ibérico do Antigo Regime, 2009 (mímeo). Agradeço ao autor por me ter facultado esse texto.

46 LISTA das pessoas que tem postos militares no sertão e das que tem capacidade para serem providos neles para melhor execução das ordens que lhe forem cometidas. ANTT. Mss. do Brasil. Livro 10, 1737.

47 CARTA de Matias Cardoso de Oliveira a José de Morais Cabral. Capão do Urucuia, 6 out. 1736. ANTT. Mss. do Brasil. Livro 1, fl.125. Agradeço a Gefferson Ramos pela cessão dessa fonte.

48 CARTA de Simeão da Cunha Pereira para Martinho de Mendonça. Tejuco, 6 fev. 1737. ANTT. Mss. do Brasil. Livro 1, fl.60-61. 
"parentesco, não significa apenas solidariedade, mas também conflito, o qual pode assumir cariz até mais virulento, em conseqüência de rancores oriundos de disputas sucessórias e da disparidade de posições patrimoniais". É preciso levar em conta "as querelas particulares de origem exógena, derivadas da permeabilidade da vida privada às lutas políticas". ${ }^{49}$

Enquanto Matias Cardoso prestava obediência ao seu rei, sua mãe, Maria da Cruz, e seu irmão, Pedro Cardoso, eram presos. O mesmo aconteceria a Domingos do Prado, se não tivesse escapado antes de ser preso.

Domingos do Prado, apontado também como um dos "principais cabeças" da revolta, era morador do arraial "chamado dos Morrinhos no distrito do governo das Minas Gerais comarca do Serro Frio". Ele era um tipo de súdito que não tinha "temor de Deus nem de Justiça". ${ }^{50}$

Assim como os demais moradores daquele sertão, Domingo do Prado era fruto de uma sociedade de fronteira e estava ciente da proteção que aquele incerto limite jurisdicional poderia Ihe trazer. Por isso, ao saber que ia ser preso, fugiu para o distrito de Pernambuco. A fronteira torna-se uma verdadeira rota de fuga para aqueles que não estavam dispostos a cumprir obrigações como verdadeiros súditos reais. Os boatos que ocorriam pelo sertão exemplifica essa instabilidade política. ${ }^{51}$ Os proprietários diziam que, se "os obrigassem a pagá-la [a capitação]", largariam suas fazendas e "iriam para a Bahia". ${ }^{52}$

Martinho de Mendonça também sabia o quanto essa jurisdição era indefinida, tanto do ponto de vista territorial, como político. Por isso, diante da tarefa de prender Domingos do Prado, achou por bem não pedir ajuda ao Conde das Galveas - André de Melo e Castro, Vice Rei da Bahia. Martinho de Mendonça estava inseguro, pois o potentado sertanejo "cuidou logo em ter amigos na relação e na secretaria" daquela comarca. O governador comentou em carta que "a pessoa do Vice Rei é inexpugnável", mas "às vezes escreve de punho próprio as ordens". Diante da possibilidade de prender aqueles criminosos em "jurisdição alheia", o governador preferiu proceder "com mais civilidade" e julgou mais apropriado "pedir ordem geral" do Vice Rei e também ao governador de Pernambuco..$^{53}$ Mesmo com

49 MELLO, Evaldo Cabral de. A fronda dos Mazombos, p.351.

50 PROPOSTA e requerimento que fazem os povos das minas gerais e os seus distritos a el rei nosso senhor que Deus guarde. s/l, s/d. ANTT. Mss. do Brasil. Livro 10, fl.204-209.

51 Análise feita por Maria Verônica Campus quando se dedicou ao estudo dos motins em Goiás na década de 1730. Para a autora, os motins de fronteira são "típicos de um contexto de expansão". Nesse território os "potentados pioneiros na abertura de uma nova frente de colonização, líderes de correntes povoadoras diversas, autoridades nomeadas pela Coroa instaladas em jurisdições limítrofes, comerciantes ligados a praças comerciais divergentes, religiosos e seculares" procuravam defender "suas províncias e bispados". Eles "entravam em disputa aberta pelo poder, pela partilha de lavras, pelas rotas comerciais, pela arrecadação de rendas e tributos criando grande instabilidade". CAMPOS, Maria Verônica. Goiás na década de 1730: pioneiros, elites locais, motins e fronteira. In: BICALHO, Maria Fernanda; FERLINI, Vera Lúcia Amaral. (orgs.). Modos de governar: idéias e práticas políticas no Império português, séculos XVI-XIX. São Paulo: Alameda, 2005, p.354.

52 CARTA de João Ferreira Tavares a Martinho de Mendonça. Lapa, 28 jun. 1736. ANTT. Mss. do Brasil. Livro 1, fl.707v.

53 CARTA de Martinho de Mendonça a Gomes Freyre de Andrada. Vila Rica. 12 dez. 1736. ANTT. Mss do Brasil. Livro 3, fls.210-213v. 
todo esse aparato, Domingos do Prado conseguiu escapar das malhas da justiça se embrenhando sertão adentro.

\section{A prisão}

Diante disso, prender uma mulher no sertão e numa região de fronteira não se configurou tarefa fácil. Nessa empreitada Martinho de Mendonça usou de muito cuidado. O governador lançou mão de sondagens e fez um cerco à personagem. Este apurado zelo para prendê-la demonstra a importância dessa teia de cumplicidade que existia entre esses potentados a partir da figura de Maria da Cruz.

O governador dizia que, "para ir à casa de Maria da Cruz é bom usar do pretexto de perguntar uma testemunha" já referida chamada Cláudia Soares que era "comadre e conhecida do General das Armas (Teodósio Duarte)". Segundo Martinho de Mendonça, poderia "fingir" que iria inquirir essa mulher, no intuito de prender Maria da Cruz, mesmo que Cláudia Soares "não saiba coisa alguma dos levantes". ${ }^{4}$

Segundo Diogo de Vasconcelos, Cláudia Soares era "amiga íntima e comadre de D. Maria da Cruz e tinha relações particulares com Teodósio Duarte". Cláudia Soares foi chamada para depor, "mas a inquirição não se limitou a parte de Teodósio unicamente". O escritor mineiro disse ainda que, nessa oportunidade, "esmerilhou-se o episódio da carta enviada por D. Maria a Domingos do Prado, da qual fora portador o ferreiro Francisco de Souza". ${ }^{5}$

Em carta do dia 7 de setembro de 1737, Simeão Cunha escreve a Martinho de Mendonça comunicando as prisões de Maria da Cruz e seu filho. Pedro Cardoso foi preso "com valor" pelo soldado Caetano Alves, em suas fazendas na localidade de Urucuia. Nessa mesma carta Simeão da Cunha Lobo comunica: "Também fica presa Maria da Cruz, prisão que executou o alferes Henrique Carlos, e um Custodio Brandão, que serviu de cabo dos sublevados", presa no Brejo do Salgado. ${ }^{56}$ Depois de presos, mãe e filho foram conduzidos para o arraial de São Romão.

Maria da Cruz, Pedro Cardoso e outros cinco presos saíram de São Romão no dia 8 de setembro, acompanhados de doze dragões comandados pelo alferes Henrique Carlos. No dia 3 de outubro, estavam em Vila Rica. Martinho de Mendonça pediu ao alferes que os mandassem "brevemente para uma fortaleza do Rio de Janeiro", onde "estarão com mais segurança".

54 INSTRUÇÃO de Martinho de Mendonça a Manuel Dias Torres. Vila Rica, 1 mai. 1737. APM. SC 61, fl. 60v. Disponível em: <http://www.siaapm.cultura.mg.gov.br>. Acesso em: 10 dez. 2010.

55 VASCONCELOS, Diogo de. História Média de Minas Gerais, p.135.

56 CARTA de Simão da Cunha Pereira a Martinho de Mendonça. São Romão, 7 set. 1737. ANTT. Livro 1 fl.69; RELAÇÃO dos presos que conduz o alferes de Dragões Henrique Carlos a ordem do Sr. Gov. São Romão, 8 set. 1737. ANTT. Livro 1, fl.71. 
O governador recomendou ainda "que poderia ser necessário repetir-Ihes as perguntas e confrontar alguns réus". ${ }^{57}$

Uma passagem imaginativa, mas belíssima sobre a prisão de Maria da Cruz foi descrita por Diogo de Vasconcelos. Segundo o escritor mineiro, no instante da prisão, a rebelde saiu de casa ao som do "alarido e pranto das mulheres, e da consternação de todos, imperturbável, com passo firme, contendo a dor que a enlouquecia, dirigiu-se ao porto pela mão do filho e saltou a barca". Maria da Cruz deixou o arraial das Pedras em direção a São Romão junto com seu filho. De lá foram levados para Vila Rica. Este trajeto foi feito em uma canoa cheia de flores em meio à angústia dos ribeirinhos. Mas ela "jamais traiu a própria dignidade, recolheu-se, porém, ao baldaquim, cerrou as cortinas e só aí se desfez em pranto".

Em agosto o crepúsculo, coando-se em laivos sanguíneos, e o ar afumarado embebendo-se de melancolia e de saudade, em quem as experimenta por dores certas, fazem, com a vida, que desaparecida toda a alegria de viver. Foi neste espasmo da alma que D. Maria atravessou todo aquele golfo e entrou no Rio das Velhas, perdendo de vista o horizonte de seus dias venturosos, e começando a sentir a noite do exílio. Com as últimas claridades que se debatiam no ocaso sua alma se foi também fechando na escuridão do destino. Depois de penosa viagem por água, a de terra foi ainda mais, até que, no fim de um mês e dias, vieram apear-se na cadeia de Vila Rica. ${ }^{58}$

Se para Diogo de Vasconcelos ela era uma heroína, para Martinho de Mendonça ela foi uma criminosa. Na tarefa de prender Maria da Cruz, o governador fez uso de um ato recorrente nas revoltas: a dissimulação. Esta característica, muito particular ao contexto das rebeliões da época, foi bastante utilizada na repressão ao motim. ${ }^{59} \mathrm{O}$ governador advertia que "não é lícito enganar positivamente a alguém". Mas era válido "nestes casos usar de engano negativo". Dizia ainda que a sua majestade sabia o quanto essa "cautela e artifício" poderia "facilitar muito a matéria das prisões". ${ }^{60}$

Ao comentar sobre a prisão de Maria da Cruz e de seu filho, Gomes Freire chegou a dar "mil vezes os parabéns" a Martinho de Mendonça pelo "bom sucesso desta diligência". Gomes Freire cumprimentava a "grande cautela" que o governador interino das minas "manejou" as prisões, pois se tratava de algo "preliminar muito próprio para este bom sucesso". ${ }^{61}$

57 CARTA de Martinho de Mendonça ao Doutor Manuel Dias Torres. Vila Rica 3 out. 1737. APM. SC 56, fl.75v. Disponível em: <http://www.siaapm.cultura.mg.gov.br>. Acessado em: dez. 2010

58 VASCONCELOS, Diogo. História Média de Minas Gerais, p.138-139.

59 A dissimulação é um recurso recorrente nas revoltas coloniais. FIGUEIREDO, Luciano Raposo de Almeida. Narrativas das rebeliões: linguagem política e idéias radicais na América Portuguesa moderna. Revista da USP, São Paulo, n.57, p.6-27, mar./mai. 2003.

60 INSTRUÇÃO de Martinho de Mendonça a Manuel Dias Torres. Vila Rica, 1 mai. 1737. APM. SC 61, fl. 60v. Disponível em: <http://www.siaapm.cultura.mg.gov.br>. Acesso em: 11 dez. 2010.

61 CARTA de Gomes Freire de Andrada a Martinho de Mendonça. Rio de Janeiro, 8 out. 1737. RAPM, Belo Horizonte, v.16, n.2, p.314-315, 1911 
As felicitações dadas ao governador reforçam o quanto foi difícil prender essas "cabeças" revoltosas que viviam nas lonjuras daquele sertão. Essas saudações demonstram a importância da personagem e a relevância de sua prisão, tarefa considerada das mais custosas.

O filho de Maria da Cruz, "um dos principais cabeças dos motins do sertão pela devassa e perguntas", chegou a "ser condenado à morte em cinco dias". Porém, "sendo tão aparentada e tão mal segura" a cadeia de Vila Rica, o governador tratou de enviar Maria da Cruz, "culpada no mesmo delito" do filho, para o Rio de Janeiro. Martinho de Mendonça recomendou que prendessem mãe e filho em "prisão mais segura". ${ }^{62}$

O governador solicitou ainda que, antes de mandar os revoltosos para o Rio de Janeiro, ${ }^{63}$ o tesoureiro dos bens dos seqüestrados daqueles motins pagasse a Maria da Cruz e Pedro Cardoso a quantia de cento e vinte e cinco mil réis. Esse valor deveria ser dado a cada três meses e usado na alimentação dos réus. Em carta do dia 17 de outubro de 1737, partia o tenente Domingos da Luz "com uma leva de presos do governo; além deles, Dona Maria da Cruz e seu filho Pedro Cardoso, cabeças principais do levante e conspiração do sertão". ${ }^{64}$

Maria da Cruz e seu filho ficaram por pouco mais de um ano no Rio de Janeiro, já que, no dia 14 de novembro 1738, o Conde das Galveas informava a Gomes Freire de Andrada a chegada deles a Salvador. André de Melo e Castro registrou que, por "uma das embarcações" que chegaram do Rio de Janeiro à costa baiana, estava na lista de "quatorze presos" Pedro Cardoso e sua mãe D. Maria da Cruz. Eles haviam sido recolhidos "em uma dessas fortalezas, onde estão com igual segurança que na cadeia". ${ }^{65}$

Mãe e filho foram julgados pelo Tribunal da Relação da Bahia, ${ }^{66}$ pois suas sentenças foram expedidas por esse conselho. Quanto à punição dos dois revoltosos, sabe-se que Pedro Cardoso foi degredado para o Rio Sene, em Moçambique, na África. André de Melo e Castro "assegurou que tinha pouca culpa e que era dos principais de sua terra e muito inteligente em minas e na cultura do tabaco". Consta na carta do secretário do Estado,

62 CARTA de Martinho de Mendonça a Gomes Freyre. Vila Rica 15 out. 1737. ANTT. Mss do Brasil. Livro 3, fl.319.

63 Se o conselho de que os rebeldes fossem levados a uma prisão segura foi seguido, é provável que tenham ficado aprisionados na fortaleza da llha das Cobras.

64 CARTA de Matinho de Mendonça a Gomes Freire. Vila Rica, 17 out. 1737. APM. SC 61, fl.11. Disponível em: <http://www.siaapm.cultura.mg.gov.br>. Acesso em: 11 dez. 2010. Maria Beatriz Nizza da Silva lembra que para os casos de "mulheres na cadeia" o recurso a prisão "eram soluções temporárias enquanto se averiguava a transgressão cometida". Segundo a autora, "a pena mais comum era a de degredo para fora da região por um tempo mais ou menos longo". Porém, ainda são raras as referências a "mulheres presas" e ainda não se possui uma "percentagem acerca da população feminina nas prisões do Brasil colonial"; SILVA, Maria Beatriz Nizza da. Donas e plebéias na sociedade colonial. Lisboa: Estampa, 2002, p.234-235.

65 CARTA do Conde das Galveas (André de Melo e Castro) a Gomes Freire de Andrada. APM. SC 66, fl.165v-166. Disponível em: <http://www.siaapm.cultura.mg.gov.br>. Acesso em: 10 dez. 2010.

66 O Tribunal da Relação da Bahia foi estabelecido no Brasil em 1609. Era o principal órgão de emprego da lei e recebia recursos de todas as instâncias judiciais. A instituição era dirigida pelo governador geral. Cf.: SCHWARTZ, Stuart B. Burocracia e Sociedade no Brasil colonial: a Suprema Corte da Bahia e seus juízes, 1609-1751. São Paulo: Perspectiva, 1979. 
Marco de Azevedo Coutinho, para o governador do Rio de Janeiro, que Pedro Cardoso foi levado para o Rio Sene onde poderia "ter exercícios as três lavouras, de açúcar, tabaco e ouro, ao que não tinha dúvida, levando logo de Moçambique bateia e almocafres, instrumentos desconhecidos naquele país". ${ }^{67}$

Apesar do degredo, Pedro Cardoso conseguiu construir nova vida..$^{68} \mathrm{O}$ filho rebelde de Maria da Cruz foi "Capitão-mor do Zimbábue, ou Corte do Imperador do Monomotapa". ${ }^{69}$ Pedro Taques, procurou apagar a mazela do rebelde Pedro Cardoso e enalteceu as virtudes que ele fez ao passar "para a Índia" onde "obrou ações de valor em uma pequena fortaleza do Rio de Sene". ${ }^{70}$ Nas terras de Moçambique, Pedro Cardoso teria ficado "persuadido", por ser "as ditas minas mais ricas que a deste Brasil e incomparavelmente de menos despesa e trabalho porque sem mudar correntes dos rios nem ser necessário fazer outros serviços" era possível tirar delas "o ouro com toda a facilidade". A carta demonstra ainda o interesse que "se passassem desse Brasil a Moçambique quarenta ou cinqüenta paulistas com suas mulheres para se irem estabelecer naqueles rios, concedendoIhes as mesmas vantagens que aí se lhe concedem", visto que "só não cultivariam com suas lavouras e criações de gado as terras e tirariam delas uma imensa cópia de ouro, mas também se conseguiria outra vantagem de abrir-se a comunicação com Angola, a qual o mesmo Pedro Cardoso segura ser factível e se oferece a execução". ${ }^{71}$

Enquanto o marido atuava em "ações de valor" em terras africanas, do lado de cá do Atlântico, a esposa de Pedro Cardoso, D. Francisca Leite, enfrentava dificuldades para continuar administrando os bens do casal. ${ }^{72}$ Segundo Pedro Taques, o "grande cabedal" de D. Francisca Leite, com-

67 CARTA do secretário de estado Marco de Azeredo Coutinho para o governador do Rio de Janeiro. Arquivo Público do Estado da Bahia (doravante, APEB). Seção Colonial e Provincial, Livro 515, Lisboa 5 abr. 1743, apud FAGUNDES, Giselle; MARTINS, Nahílson. Alvará de perdão concedido a Dona Maria da Cruz, viúva, Montes Claros: [edição do autor], 2006, p.58-59.

68 Em recente trabalho André Figueiredo Rodrigues mostra como o degredo também pode ser sinônimo de um recomeço. FIGUEIREDO, André Rodrigues. Estudo econômico da Conjuração Mineira: análise dos seqüestros de bens dos inconfidentes da comarca do Rio das Mortes. São Paulo: Universidade de São Paulo, 2008 (História, Tese de doutorado).

69 CARTA do secretário de estado Marco de Azeredo Coutinho para o governador do Rio de Janeiro. APEB. Seção Colonial e Provincial, Livro 515, Lisboa 5 abr. 1743, apud FAGUNDES, Giselle; MARTINS, Nahílson. Alvará de perdão concedido a Dona Maria da Cruz, viúva, p.58-59.

70 LEME, Pedro Taques de Almeida Paes. Nobiliarquia paulistana histórica e genealógica. v.lll. 5 ed. Belo Horizonte/ São Paulo: Itatiaia/Edusp, 1980, p.89. O genealogista não fez referências aos motivos que levaram Pedro Cardoso a essa condição. O filho de Maria da Cruz descendia dos paulistas que ocuparam aquelas terras e era importante em sua narrativa apagar seus "vícios". Segundo Laura de Mello e Souza, Pedro Taques procurou "enterrar de vez os vícios e fazer prevalecer as virtudes" dos paulistas conquistadores. SOUZA, Laura de Mello e. O sol e a sombra, p. 140

71 CARTA do secretário de estado Marco de Azeredo Coutinho para o governador do Rio de Janeiro. APEB. Seção Colonial e Provincial, Livro 515, Lisboa 5 abr. 1743, apud FAGUNDES, Giselle; MARTINS, Nahílson. Alvará de perdão concedido a Dona Maria da Cruz, viúva, p.58-59.

72 PIJNING, Ernst. Norms and values of the Brazilian interior: a study of eighteenth-century testaments from Serro Frio, Minas Gerais. (mimeo), s/l, s/d, p.6. Agradeço a Luciano Figueiredo pela cessão desse texto. 
posto por "rendosas fazendas de gado" no sertão das minas, herdaram seus irmãos. ${ }^{73}$

\section{O perdão}

Maria da Cruz foi julgada e "condenada a cem mil réis para as despesas da Relação e em seis anos de degredo para um dos lugares da África". As desconfianças de Martinho de Mendonça se comprovaram aos olhos da justiça, pois a rebelde foi "presa e seqüestrada pela culpa que resultara da devassa que se tirara do levantamento do povo do rio de São Francisco". ${ }^{74}$

Entretanto, no dia 9 de abril de 1739, Maria da Cruz recebeu carta de perdão "por graça de Deus Rei de Portugal e Algarves". A notícia deveria ser dada a "todos os corregedores, provedores, ouvidores, juízes, justiças, oficiais e mais pessoas dos ditos reinos e senhores" a que aquela missiva fosse mostrada. ${ }^{75} \mathrm{O}$ crime de Maria da Cruz foi julgado. Ela foi culpada e condenada pela sua transgressão. No entanto, a figura do rei piedoso prevaleceu.

O recurso do perdão coletivo aos revoltosos era uma prática comum nos motins coloniais. ${ }^{76}$ Os súditos sertanejos também pediram clemência real durante a própria revolta em que Maria da Cruz esteve envolvida. Os rebeldes diziam em voz alta que atuavam "com humildade de fiéis e leais vassalos de El Rei de Portugal". Rogavam a sua majestade e pediam que usasse de seu "generoso ânimo e tão caritativo com que costuma ouvir os que vão aos seus pés". Os revoltosos clamavam que o rei fosse misericordioso e que concedesse o "perdão geral para todos", aproveitavam para pedir que restituísse tudo que foi confiscado e que cada um "se habitue e tome posse dos seus sítios na forma em que os possuía". Queriam também que sua majestade os livrasse dos "tributos destes quintos", já que não assistiam "terras de Minas e ouro que aparece é de negócio". ${ }^{77}$

73 LEME, Pedro Taques de Almeida Paes. Nobiliarquia paulistana histórica e genealógica, p. 89

74 ALVARÁ de Perdão Concedido a Dona Maria da Cruz, Viúva. Salvador, Bahia de Todos os Santos. 9 abr. 1739 APEB. Seção Colonial Provincial. Tribunal da Relação/Alvarás e Provisões, 1738-1739. Livro 515, apud FAGUNDES, Giselle; MARTINS, Nahílson. Alvará de perdão concedido a Dona Maria da Cruz, viúva, p.59-60.

75 ALVARÁ de Perdão Concedido a Dona Maria da Cruz, Viúva. Salvador, Bahia de Todos os Santos. 9 abr. 1739 APEB. Seção Colonial Provincial. Tribunal da Relação/Alvarás e Provisões, 1738-1739. Livro 515, apud FAGUNDES, Giselle; MARTINS, Nahílson. Alvará de perdão concedido a Dona Maria da Cruz, viúva, p.59-60.

76 Adriana Romeiro comenta, por exemplo, como a "concessão de indulto a paulistas e emboabas" também pode ser visto dentro das "particularidades da zona mineradora". Para a autora a "questão geográfica" deve ser levada em conta "como um dos fatores decisivos na natureza das relações da Coroa com os vassalos mineiros: muito freqüentemente as condições efetivas de uma repressão militar pesaram mais que as formulações políticas sobre o imperativo da magnanimidade régia". ROMEIRO, Adriana. Paulistas e emboabas no coração das Minas: idéias, práticas e imaginário político no século XVIII. Belo Horizonte: Editora da UFMG, 2008. p.304. Para Russel-Wood, o "recurso ao perdão merece maiores estudos. Constituíam não apenas uma estratégia de colocar termo a situações de instabilidade, mas também como um reconhecimento tácito da inabilidade das autoridades em controlar de forma mais segura e acertada a oposição e em suprimir revoltas de maior porte". RUSSELL-WOOD, A. J. R. Centro e periferia no mundo luso-brasileiro, 1500-1808. Revista Brasileira de História, v.8, n.36, p.187-249, 1998.

77 PROPOSTA e requerimento que fazem os povos das minas gerais, e os seus distritos a el-rei nosso senhor que deus guarde. s/l, s/d. ANTT. Mss. do Brasil, Livro 10, fl.204-209. 
O Discurso Histórico, documento produzido para justificar a execução sumária de Filipe dos Santos na revolta de Vila Rica, em 1720, dizia que o perdão era uma "regalia suprema do soberano". Porém, "o pode por uma ordem de onze de janeiro de mil setecentos e dezenove, em extrema necessidade conceder o governador, como é de crer que não quisesse El-Rei nosso senhor que também em extrema necessidade castigasse o mesmo governador, como lhe fosse possível, as sublevações?" Logo:

O castigo, com mais ou menos circunstancias, é ação que cabe no foro dos generais, o perdão é graça que só toca à soberania dos príncipes, e onde o príncipe concede a sua autoridade no perdão, que é mais, visto está que não havia de negar essa mesma autoridade no castigo, que é menos. ${ }^{78}$

Maria da Cruz, ao contrário de Felipe dos Santos, teve um destino diferente. Ela foi absolvida de sua transgressão. Mas por que ser piedoso com uma mulher amotinada e moradora daquele sertão "bárbaro"?

As cartas de perdão da França do século XVI analisadas por Natalie Davis iluminam algumas questões sobre a clemência dada a Maria da Cruz. A autora faz um estudo sobre as formas de linguagem presentes nessas epístolas e mostra como as pessoas contavam suas próprias histórias através dos pedidos. As cartas servem como instrumento jurídico através do qual os súditos da França do século XVI pediam clemência ao rei pelo homicídio que haviam cometido. A historiadora mostra que as cartas de perdão também estão atreladas à criação do caráter de cada narrador. Segundo Natalie Davis, no caso das cartas de perdão de mulheres havia uma nítida preocupação com o estado de espírito e mental das mesmas. Esses dois elementos são bastante utilizados nos pedidos de remissão feminino. ${ }^{79}$

Apesar de se tratar de contexto e épocas diferentes, nota-se uma estratégia persuasiva similar na carta de perdão de Maria da Cruz. Sua missiva informava que,

tinha a suplicante sua casa, fazendas, e famílias, e por estar já acostumada com o clima daquele sertão, tinha experimentado muitas queixas no tempo que se tem passado depois que dele saíra, por causa da referida prisão, e, caso que tivesse melhora, Ihe era muito preciso e conveniente ver a sua casa e fazendas, para que de todo não se perdessem; outrossim se achava a suplicante impossibilitada de satisfazer a sua pecuniária, não só pelo seqüestro que se fizera em seus bens, mas também pelos descaminhos que tiveram com a sua prisão, tanto assim que

78 DISCURSO Histórico e Político sobre a sublevação que nas Minas houve no ano de 1720, p.177-178. João Henrique Ferreira de Castro discute acerca do papel da punição na Revolta de Vila Rica em 1720. O autor procura entender o papel da punição e do perdão na cultura política portuguesa a partir de meados do século XVII e durante as primeiras décadas do XVIII. CASTRO, João Henrique Ferreira de. A repressão à Revolta de Vila Rica de 1720: perdão e punição sob a ótica da justiça no Império Ultramarino Português. Rio de Janeiro: Universidade Federal do Rio de Janeiro, 2012 (História, Dissertação de mestrado).

79 DAVIS, Natalie Zemon. Histórias de perdão e seus narradores na França do século XVI. São Paulo: Companhia das Letras, 2001, p.162. 
nas minas chegara a viver de esmolas, e no Rio de Janeiro a socorrera o bispo, e nesta cidade seu genro, o coronel Domingos Martins Pereira, ao que acresciam os muitos trabalhos que ela tinha padecido na rigorosa e dilatada prisão. ${ }^{80}$

A dramaturgia do corpo debilitado se faz presente como estratégia persuasiva. O texto de sua remissão destaca as "queixas", os "descaminhos", a "rigorosa e dilatada prisão", e até mesmo a vontade de Maria da Cruz em voltar para sua casa. A manipulação do sentimento de perdão também atravessa o estado, espírito e corpo feminino; ele é a sua honra. ${ }^{81}$ Aqui ela aparece mais como súdita fiel e já sofrida por seus delitos do que como transgressora. Era hora de apresentar uma mulher mais condolente, por isso uma carta escrita ao tom da súplica.

É possível que o fato da suplicante ser viúva também influenciasse na hora da clemência de Sua Majestade. Segundo Natalie Davis, quando se trata de mulheres amotinadas é preciso considerar o que vem por trás dos discursos. Para a autora, havia uma "complexa licença dada à mulher desordeira". Acreditava-se que a mulher seria encaminhada à revolta devido ao "impulso de seus baixos instintos", pois "ela não era responsável por suas ações". O marido era o grande culpado por seus atos, "já que estava sujeita a ele". ${ }^{82}$ O esposo de Maria da Cruz não estava mais vivo, logo, não podia assumir a culpa por ela. Talvez por isso a sua carta de perdão fez questão de declarar que ela era "viúva do coronel Salvador Cardoso de Oliveira". ${ }^{83}$

A raiva feminina também era menos punível em alguns casos. A fúria delas era mais aceitável "na defesa dos filhos ou da religião, num motim por alimentos ou num levante religioso, ou em defesa de seu país, como nos casos de Judite e Joana d'Arc". Os crimes como bruxaria e infanticídio eram imperdoáveis. ${ }^{84}$ Portanto, a ira da mulher se justificava em ações situadas no espaço que lhe era próprio: o mundo particular.

As mulheres daquela época tinham o hábito de emocionar "a multidão com a sua presença" porque sabiam que eram capazes de preocupar as autoridades. Assim, "elas pouco temem", já que eram "menos puníveis". ${ }^{5}$ No caso de Maria da Cruz, apesar de ter sido condenada, a clemência régia falou mais alto.

80 ALVARÁ de Perdão Concedido a Dona Maria da Cruz, Viúva. Salvador, Bahia de Todos os Santos. 9 abr. 1739 APEB. Seção Colonial Provincial. Tribunal da Relação/Alvarás e Provisões, 1738-1739. Livro 515, apud FAGUNDES, Giselle; MARTINS, Nahílson. Alvará de perdão concedido a Dona Maria da Cruz, viúva, p.59-60.

81 "Cada uno o cada uma 'manipula' el sentimiento que tiene de su honor e intenta mostrarse como um digno súbdito del Rey que solo cometió una falta para defender esse hono pisoteado y, por lo tanto, também el del Rey". FARGE, Arlette. Efusión e tormento: el relato de los cuerpos. Historia del Pueblo en el siglo XVIII. Trad. Julia Bucci. Madrid: Katz, 2008, p.105.

82 DAVIS, Natalie Zemon. Histórias de perdão e seus narradores na França do século XVI, p.116-124.

83 ALVARÁ de Perdão Concedido a Dona Maria da Cruz, Viúva. Salvador, Bahia de Todos os Santos. 9 abr. 1739. APEB. Seção Colonial Provincial. Tribunal da Relação/Alvarás e Provisões, 1738-1739. Livro 515, apud FAGUNDES, Giselle; MARTINS, Nahílson. Alvará de perdão concedido a Dona Maria da Cruz, viúva, p.59-60.

84 DAVIS, Natalie Zemon. Histórias de perdão e seus narradores na França do século XVI, p.116-124.

85 FARGE, Arlette. Agitadoras notórias, p.560. 
A remissão dada a Maria da Cruz pode ser entendida como um dos atributos do "senhor indulgente", próprio do exercício de governo daquele período. Pedro Cardim ressalta que do "senhor que prezava os seus vassalos esperava-se, acima de tudo, amor, mas também justiça". Essa noção estava associada ao "esforço para repor a ordem, para regressar à harmonia momentaneamente desfeita, tudo fazendo para que em nenhuma das partes ficassem sequelas do conflito". ${ }^{86}$

A clemência régia era também uma forma de legitimação do poder do rei. ${ }^{87}$ Nesse sentido, o poder de perdoar conferia à figura da realeza o caráter de justiceiro. Assim, ele garantia a associação de sua imagem à de pastor e pai. A própria carta de perdão dizia que Maria da Cruz "pedia pelas divinas chagas de Cristo Senhor Nosso, e sua sagrada morte e paixão pela qual neste santo dia costumava perdoar maiores penas e condenações", que Ihe remitisse "do referido degredo e proibição de tornar ao sítio das Pedras em que morava" e lhe diminuir "a pena pecuniária". ${ }^{88}$ Logo, a mesma mão que ameaçava com castigos impiedosos também era capaz de conceder a graça. Estava construído então o paradoxo entre o terror e a clemência que neste contexto constituía-se, ao mesmo tempo, justiça e graça. A figura do rei piedoso assemelhava-se a Deus, metáfora da figura do Pai justiceiro e do Filho doce e amável. ${ }^{89}$

Nos casos de "sedição", onde houvesse um claro "levantamento do povo contra a autoridade Del Rei ou dos Magistrados", deveria se conter com "temor" ou "clemência". Isso foi destacado por Rafhael Bluetau em seu dicionário produzido na primeira metade do século XVIII. Porém, ressalta o autor, seria de grande perigo que as desordens "criem raízes e afiguram seu princípio; por que são como ribeiras, que quando mais correm, mais crescem". ${ }^{90} \mathrm{O}$ ato de perdoar os súditos era um atributo da governabilidade. Evaldo Cabral de Mello ressalta também que, em contrapartida, a remissão pode ser uma "medida prática, ao encorajar as delações e a averiguação das responsabilidades". ${ }^{91}$

86 CARDIM, Pedro António Almeida. O poder dos afectos: ordem amorosa e dinâmica política no Portugal do Antigo Regime. Lisboa: Universidade Nova de Lisboa, 2000 (História, Tese de Doutorado). Capítulo 4 "Uma ordem amorosa" subtítulo: "O amor e o perdão", p.278-292. Disponível em: <http://www.estig.ipbeja.pt/ ac_direito/ ACS MA 6100.pdf>. Acesso em: mar. 2011.

87 BICALLHO, Maria Fernanda. Crime e castigo em Portugal e seu Império. Topoi, Rio de Janeiro, n. 1, p.224-231, 2000. Neste artigo, a autora analisa a obra: ORDENAÇÕES Filipinas. Livro V. Introdução, notas e cronologia de Silvia Hunold Lara. São Paulo: Companhia das Letras, 1999

88 ALVARÁ de Perdão Concedido a Dona Maria da Cruz, Viúva. Salvador, Bahia de Todos os Santos. 9 de abril de 1739. APEB. Seção Colonial Provincial. Tribunal da Relação/Alvarás e Provisões, 1738-1739. Livro 515, apud FAGUNDES, Giselle; MARTINS, Nahílson. Alvará de perdão concedido a Dona Maria da Cruz, viúva, p.59-60.

89 HESPANHA, António Manuel. A punição e a graça. In: MATOSO, José. (dir.). História de Portugal: o Antigo Regime: 1620-1807. Lisboa: Estampa, 1991, p.239-256.

90 BLUTEAU, Raphael. Vocabulário portuguez e latino, p.544.

91 MELLO, Evaldo Cabral de. A fronda dos Mazombos, p.360. Rodrigo Bentes Monteiro ressalta como o recurso ao perdão régio na restauração pernambucana foi usado como "cooptação para a ordem social, que naquele momento era definida pela defesa urgente da terra portuguesa, mais do que pelos crimes cometidos". Segundo o autor, "sacrificava-se a aplicação da justiça em prol da manutenção do território, aspecto significativo em se 
A indulgência régia pode ser entendida como uma forma de castigo. Assim como a punição exemplar, o perdão também alcançava a coletividade. Conceder a clemência a uma mulher viúva era a melhor forma de acalmar os ânimos e estender o poder régio em um sertão inóspito e difícil de chegar.

A revolta acabou. Castigo e perdão foram concedidos. Houve mortes, prisões e contenção dos rebeldes. O que fazer agora? Os "homens retornam a seu trabalho" e a seus afazeres cotidianos, enquanto as mulheres "fazem a mesma coisa", porém isso não significa necessariamente o mesmo. Elas voltam a sua rotina onde a "parte civil e política está ausente". ${ }^{92}$ Entretanto, para ela, a revolta não acaba assim. Se os homens são os que mais sofrem com as punições, cabe à figura feminina ser a nova administradora do patrimônio familiar, sem falar nos dissabores que ela irá enfrentar, caso os bens do seu marido fossem confiscados.

Maria da Cruz era viúva e tudo indica que seus bens foram "seqüestrados" ${ }^{93}$ Depois de receber a graça régia ela voltou para sua fazenda no sítio das Pedras. Em seu testamento rogou:

Sendo Deus Nosso Senhor servido levar-me para si na dita minha fazendo das Pedras, ordeno que o meu corpo será sepultado na minha capela da Nossa Senhora da Conceição na mesma sepultura de meu marido, o coronel Salvador Cardoso. ${ }^{94}$

Seu testamento, com data do dia 13 de setembro de 1739, foi feito em Vila de Santo Amaro da Purificação, no recôncavo baiano, onde morava o seu genro Domingos Martins Pereira. Ele ficaria de Ihe emprestar "duzentos mil réis" para que ela voltasse para o sertão. Apesar de sua carta de perdão informar que seus bens haviam sido confiscados, Maria da Cruz, se não recuperou todas as suas posses, garantiria, em 1745, carta de sesmaria assinada por Gomes Freire de Andrada. Trata-se do mesmo governador que havia parabenizado Martinho de Mendonça pelo "bom sucesso" na sua prisão anos atrás. A graça que conseguiu de seu rei já citava a possibilidade Maria da Cruz recuperar suas posses. Na sua carta de perdão

tratando de Pernambuco". MONTEIRO, Rodrigo Bentes. O rei no espelho: monarquia portuguesa e a colonização na América, 1640-1720. São Paulo: Hucitec, 2002, p.233.

92 FARGE, Arlette. Agitadoras notórias, p.571

93 Em carta destinada a Martinho de Mendonça foi registrado o seguinte: "Entre os culpados, reputo por principal cabeça, um Domingos do Prado Paulista muito rico, D. Maria da Cruz, e seu filho Pedro Cardozo sobrinho do dito Prado, a quem senão fez ainda seqüestro, com prudente consideração do Ministro, por entender que com alguma cautela seria fácil prendê-los depois, o que então não tinha lugar, por andarem retirados, como também por não caber no tempo fazer seqüestros em fazendas de gados que possuem, estando tão adiantada a estação e eminentes cheias, que fazem aquele país impraticável; porem esta diligência fica muito no meu cuidado para recomendar a pessoa a quem entregar o governador, ou a fazer executar tanto q o tempo, o permitir". CARTA de Antonio Guedes Pereira a Martinho de Mendonça. Vila Rica, 2 jan. 1736. RAPM, Ouro Preto, v.1, n.4, p.662-663, 1896.

94 TESTAMENTO de Maria da Cruz. Vila de Santo Amaro da Purificação (Recôncavo Baiano). 13 set. 1739. Fórum Edmundo Lins do Rego - Serro - MG, apud FAGUNDES, Giselle; MARTINS, Nahílson. Alvará de perdão concedido a Dona Maria da Cruz, viúva, p.60. 
estava escrito que, quanto a "restituição às suas fazendas, use dos meios ordinários". ${ }^{95}$

Gomes Freire de Andrada passou carta de sesmaria a "Dona Maria da Cruz, moradora no sertão do rio de São Francisco, comarca da Vila Real". Ela "era senhora e possuidora de uma fazenda chamada Capão situada no sertão do rio São Francisco". O governador relatou não ter "dúvida na concessão desta sesmaria por não encontrarem inconveniente que a proibisse". A propriedade de Maria da Cruz era vizinha a de seu filho, padre Manoel Cardoso. Gomes Freire "em nome de sua majestade" a concedeu, em 4 de maio de 1745, "três léguas e meia em quadra". ${ }^{96}$

Houve um número elevado de doações de sesmarias para a região do sertão depois da revolta, apontou Gefferson Ramos Rodrigues. Segundo o autor, essas concessões podem ser entendidas como "medida de acomodação". ${ }^{97}$ A carta de sesmaria de Maria da Cruz se insere nesse contexto. Ela, assim como alguns outros moradores daquela localidade, não tinha carta de sesmaria. Maria da Cruz recebeu o título de sesmeira nas imediações do mesmo lugar onde tinha sua propriedade antes da revolta. A concessão dessa mercê é mais uma prova da benevolência de seu rei e da vontade de sua majestade em sossegar aquele território.

Analisar o "retorno ao quotidiano é uma questão difícil". Vários sentimentos podem surgir, desde o "orgulho de ter participado", até a aceitação da "ordem das coisas com altos e baixos". As mulheres "podem ser as primeiras, depois as últimas" a sair da revolta, lembrou Arlette Farge. ${ }^{98}$

Maria da Cruz foi mesmo a última a sair dos conflitos. Sua carta de perdão relatava as "muitas queixas" que a rebelde tinha enfrentado desde que tinha saído de casa devido à prisão, e "Ihe era muito preciso e conveniente ver a sua casa e fazendas" ${ }^{99}$ Ela viveu muitos anos ainda, pois seu testamento foi aberto em 23 de junho de 1760, e dizia o seguinte:

Aos vinte três dias do mês de junho de mil setecentos e sessenta abri o testamento com que faleceu Dona Maria da Cruz, viúva que ficou do coronel Salvador Cardoso, moradora no sítio da capela chamada Nossa Senhora da Conceição das Pedras, filial desta matriz do arraial dos Morrinhos, o qual testamento me apresentou o padre Manoel Cardoso de Toledo, morador no dito lugar da capela das Pedras. ${ }^{100}$

95 ALVARÁ de perdão concedido a dona Maria da Cruz, viúva. Salvador, Bahia de Todos os Santos. 9 abr. 1739. APEB. Seção Colonial Provincial. Tribunal da Relação/Alvarás e Provisões, 1738-1739. Livro 515, apud FAGUNDES, Giselle; MARTINS, Nahílson. Alvará de perdão concedido a Dona Maria da Cruz, viúva, p.59-60.

96 CARTA de sesmaria, 4 mai. 1745. RAPM, Ouro Preto, v.2, p.891, 1898.

97 ROGRIGUES, Gefferson Ramos. No sertão, a revolta, p.45.

98 FARGE, Arlette. Agitadoras notórias, p.571.

99 ALVARÁ de Perdão Concedido a Dona Maria da Cruz, Viúva. Salvador, Bahia de Todos os Santos. 9 abr. 1739. APEB. Seção Colonial Provincial. Tribunal da Relação/Alvarás e Provisões, 1738-1739. Livro 515, apud FAGUNDES, Giselle; MARTINS, Nahílson. Alvará de perdão concedido a Dona Maria da Cruz, viúva, p.59-60.

100 TESTAMENTO de Maria da Cruz. Vila de Santo Amaro da Purificação (Recôncavo Baiano). 13 set. 1739. Fórum Edmundo Lins do Rego - Serro - MG, apud FAGUNDES, Giselle; MARTINS, Nahílson. Alvará de perdão concedido a Dona Maria da Cruz, viúva, p.60. 
Mulher setecentista, contemporânea de uma sociedade que se preocupava com a salvação da alma, deixou em seu testamento o desejo de ter uma morte tranqüila. ${ }^{101}$ Maria da Cruz pediu que seu corpo fosse "amortalhado no hábito do patriarca de São Francisco" e suplicou ainda que celebrassem por sua "alma às missas que puder ser". ${ }^{102}$

Maria da Cruz foi perdoada e seu filho degredado. Prêmio e castigo se misturam em prol do bom governo. Era preciso punir para servir de exemplo, mas era necessário também criar medidas para acalmar os ânimos daquele sertão. A clemência dada a uma mulher viúva, acostumada com o "clima daquele sertão"- como diz sua carta de perdão, pode ser entendida como exemplo da arte da governabilidade naquele período. Mulher e cena política compõem, através do exercício de indulgência régia, uma forma de estender a braços do poder real àquelas lonjuras.

Estudar a trajetória de Maria da Cruz e retirá-la da sua "fria e apagada cova", ${ }^{103}$ feito que muito alegrou Diogo de Vasconcelos quando escreveu sobre a personagem, é semelhante à pesquisa da história das mulheres. Este é um domínio da História onde se "recolhe uma espécie extinta, uma flor desconhecida, faz seu retrato como quem repara um esquecimento" e distingue o "seu vestígio como quem exibe uma morta". Afinal, "tornar visível a mulher quando a história se abstinha de vê-la" não é tarefa fácil. ${ }^{104}$

101 Para entender melhor os ritos fúnebres nas Minas setecentistas, principalmente no caso de forros e livres, cf. FURTADO, Júnia Ferreira. Transitoriedade da vida, eternidade da morte: ritos fúnebres de forros e livres nas Minas setecentistas. In: JANCSÓ, Istvan; KANTOR, Íris. (orgs). Festa: cultura e sociabilidade na América portuguesa. v.1, São Paulo: Hucitec: Edusp: Fapesp: Imprensa Oficial, 2001, p.397-416; REIS, Liana Maria. Mulheres de Vila do Carmo: a preocupação com a "Boa Morte". (1713-1750). Temporalidades - Revista Discente do Programa de Pós-graduação em História da UFMG, Belo Horizonte, v.1, n.2, ago./dez. 2009.

102 TESTAMENTO de Maria da Cruz. Vila de Santo Amaro da Purificação (Recôncavo Baiano). 13 set. 1739. Fórum Edmundo Lins do Rego - Serro - MG, apud FAGUNDES, Giselle; MARTINS, Nahílson. Alvará de perdão concedido a Dona Maria da Cruz, viúva, p.60.

103 VASCONCELOS, Diogo de. História Média de Minas Gerais, p.100.

104 FARGE, Arlette. O sabor do arquivo, p.37. 